\title{
PENGARUH JOB CHARACTERISTICS DAN LEADER MEMBER EXCHANGE (LMX) TERHADAP WORK ENGAGEMENT DI PT ELANG PERDANA TYRE INDUSTRY
}

\author{
THE EFFECT OF JOB CHARACTERISTICS AND LEADER MEMBER EXCHANGE (LMX) ON \\ WORK ENGAGEMENT IN PT ELANGPERDANA TIRE INDUSTRY
}

\author{
Nurdiani Komala Dewi ${ }^{*}$, Aji Hermawan ${ }^{*}$ dan M.Joko Affandi ${ }^{* *}$ \\ *) Sekolah Bisnis, IPB University \\ Jl. Raya Pajajaran, Bogor 16151 \\ ${ }^{* *}$ PPM Manajemen \\ Jl. Menteng Raya 9, Jakarta 10340
}

\begin{abstract}
Work engagement is an important concept in employee work behavior in organizations. This study aims to examine the direct positive effect of job characteristics and leader-member exchange (LMX) on work engagement and examine the role of LMX as a moderating variable on the influence of job characteristics on work engagement. A total of 395 samples were employees at PT Elangperdana Tire Industry. The model in this study was analyzed by SEM (Structural Equation Modeling) method. The results showed that job characteristics and LMX directly and positively affected the work engagement. In addition, $L M X$ showed a role as a moderating variable that influenced of job characteristics on work engagement. In other words, the better relationship of LMX increased the influence of job characteristics on work engagement.
\end{abstract}

Keywords: job characteristics, leader member exchange, LMX, work engagement, SEM

\begin{abstract}
Abstrak: Work engagement merupakan konsep yang penting dalam perilaku kerja karyawan di organisasi. Penelitian ini bertujuan menguji pengaruh positif secara langsung job characteristics dan leader member exchange (LMX) terhadap work engagement dan menguji peran LMX sebagai pemoderasi pada pengaruh job characteristics terhadap work engagement. Sebanyak 395 kuesioner yang dapat diolah dalam penelitian ini dimana sampel diambil dari karyawan di PT Elangperdana Tyre Industry. Pengujian model dalam penelitian ini menggunakan metode SEM (Structural Equation Modeling). Hasil penelitian menunjukkan job characteristics dan LMX mempengaruhi secara langsung dan positif signifikan terhadap work engagement. Selain itu, LMX menunjukkan peran sebagai pemoderasi dalam pengaruh job characteristics terhadap work engagement. Dengan kata lain, semakin baiknya LMX dapat meningkatkan pengaruh job characteristics terhadap work engagement.
\end{abstract}

Kata kunci: job characteristics, leader member exchange, LMX, work engagement, SEM

\footnotetext{
${ }^{1}$ Corresponding author:

Email: nurdianikomala@gmail.com
} 


\section{PENDAHULUAN}

Organisasi menghadapi kondisi yang sulit dengan kompetisi yang semakin tajam dalam 25 tahun terakhir, karena adanya arus globalisasi, perkembangan komunikasi dan teknologi informasi yang terjadi sangat cepat. Perubahan dan pengembanganyang adaptif dapat menciptakan keunggulan bersaing sehingga organisasi akan berdaya untuk berprestasi dalam melanjutkan keberlangsungan usaha dan mencapai efektifitas dan kinerja yang diharapkan oleh organisasi. Untuk sukses mengimplementasi berbagai perubahan, organisasi perlu mengatur dan mengorganisasi banyak faktor pada berbagai tingkat, yaitu, sosial, organisasi, departemen dan individual.Perubahan pada kebijakan-kebijakan, praktik dan sistem yang disusun, dapat memengaruhi sikap, perilaku dan kinerja karyawan (Noe et al. 2006).

Aspek emosional karyawan pada pekerjaan penting bagi organisasi karena akan memengaruhi efisiensi, produktifitas dan keunggulan bersaing (competitive advantage) organisasi (Wellins et al. 2006). Oleh karena itu, organisasi perlu mengikat sikap kerja karyawan yang menunjukkan perilaku organisasi positif.Menurut Bakker dan Schaufeli (2008) salah satu sikap kerja yang menunjukkan kondisi mental positif, yang kemudian mendorong perilaku kerja yang positif adalah work engagement. Bakker (2014) menjelaskan bahwa karyawan yang engagedakan terdorong untuk melakukan tujuan yang menantang dalam pekerjaannya. Karyawan juga memiliki keinginan untuk sukses dan memiliki komitmen pribadi untuk mencapai tujuan, karena karyawan tersebut giat bahkan memiliki antusiasme untuk mengeluarkan energi yang mereka miliki untuk bekerja (Demerouti et al. 2001).

Teori Job Demand-Resources (JD-R) yang dikemukakan oleh Demerouti et al. (2001), Schaufeli dan Bakker (2004) menjelaskan faktor-faktor yang dapat memunculkan work engagement. Job Demand (tuntutan pekerjaan) dan Job Resources (sumber daya dari pekerjaan) meliputi, aspek fisik, sosial dan organisasi. Job Resources (sumber daya dari pekerjaan) dapat menurunkan job demand (tuntutan pekerjaan) yang berhubungan dengan biaya fisiologis dan psikologis, membantu mencapai target dan tujuan pekerjaan serta dapat menstimulasi pertumbuhan, pembelajaran dan pengembangan pribadi karyawan.
Work engagement merupakan diferensiasi dari konstruk motivasi kerja, komitmen, keterlibatan, kepuasan kerja (Macey dan Scheinder, 2008; Meyer dan Gagne, 2008). Menurut Schaufeli et al. (2002) work engagement lebih menekankan pada tingginya semangat yang dimanifestasikan dalam aktifitas kerja (vigor dan absorption) dan tingginya kegembiraan dalam bekerja (dedication). Pekerjaan karyawan dan hubungan atasan-bawahan serta pengaruhnya pada peningkatan work engagement merupakan bagian yang tidak dapat dipisahkan dalam pengelolaan SDM di perusahaan. Bakker (2011) mengungkapkan bahwa job resources dapat menjadi motivasi intrinsik dan ekstrinsik yang akan meningkatkan kesungguhan seseorang untuk mendedikasikan diri dalam pekerjaannya.

Job characteristics merupakan salah satu job resources yang secara konsisten menunjukan hubungan yang positif dengan work engagement. Hackman dan Oldham (1975) menyusun model karakteristik pekerjaan dengan dimensi-dimensinya, antara lain; keberagaman keahlian (skill variety), identitas tugas (task identity),signifikansi tugas (task significance), otonomi (autonomy), dan umpan balik (feedback). Teori job characteristics menjelaskan bahwa dimensinya dapat memengaruhi hasil kerja dan motivasi karyawan dengan mendorong kondisi psikologis berupa kebermaknaan dalam pekerjaan, munculnya rasa tanggung jawab terhadap hasil pekerjaan dan rasa kepedulian terhadap dampak yang terjadi dari pekerjaan yang telah dilakukan oleh karyawan.

Pemimpin juga dapat memengaruhi lingkungan kerja karyawan sehingga secara tidak langsung memengaruhi kesejahteraan karyawan dan kinerjanya (Bakker dan Demerouti, 2008). Hubungan atasan-bawahan menjadi sangat penting pada pekerjaan.Atasan atau pemimpin dalam bekerja menjalankan berbagai fungsi manajerial dari perencanaan, pengorganisasian, penggerak, dan pengawasan. Tugas-tugas manajerial tersebut tidak dapat dicapai hanya oleh pimpinan seorang diri, tetapi dengan menggerakkan orang-orang yang dipimpinnya.Kualitas hubungan atasan dan bawahan memengaruhi persepsi, sikap dan perilaku, baik atasan maupun bawahan yang memiliki hubungan tersebut. Teori mengenai hubungan antara pemimpin dengan karyawan ini disebut dengan Leader Member Exchange (LMX), yaitu pemimpin membangun suatu tipe hubungan timbal balik yang berbeda-beda terhadap para karyawan yang ada (Graen dan UhlBien, 1995). Teori LMX lebih jauh menjelaskan bahwa 
karyawan yang mengalami hubungan LMX berkualitas rendah tidak mungkin berkontribusi melampaui upaya minimal yang dibutuhkan dalam bekerja.Sedangkan, karyawan yang mengalami hubungan LMX berkualitas tinggi cenderung berkontribusi melampaui persyaratan minimum pekerjaan. Kecenderungan perilaku kerja yang positif karena adanya perasaan bersama, kesetiaan, komitmen, dukungan, dan kepercayaan, yang dapat meningkat dari waktu ke waktu (Uhl-Bien dan Maslyn, 2001). Organisasi perlu mengetahui bagaimana interaksi atasan dan bawahan dapat meningkatkan work engagement untuk meningkatkan performa kerja, sehinggamencapai keunggulan organisasi.

Job characteristics dan LMX merupakan job resources yang penting untuk diteliti mengenai pengaruhnya terhadap work engagement. Meningkatkan work engagement sangat penting bagi organisasi, karena karyawan yang engaged menunjukkan sikap kerja yang proaktif dan berkomitmen untuk memenuhi standar kinerja yang tinggi (Bakker dan Leiter, 2010). Penelitian yang dilakukan oleh Bakker et al. (2012) menemukan bahwa work engagement memiliki hubungan yang positif dengan kinerja karyawan. Bakker dan Bal (2010) juga membuktikan bahwa work engagement memiliki hubungan yang positif dengan prestasi kerja mingguan. Karyawan yang engaged mampu menciptakanjob resources untuk meraih prestasi kerja. Hakanen dan Koivumaki (2014) menemukan bahwa work engagement memiliki hubungan positif dengan produktivitas. Work engagement dapat membantu perusahaan meraih profit yang diinginkan, karena produktifitas organisasi ditentukan oleh usaha dan keterikatan karyawan pada pekerjannya (Hanaysha, 2016).

Penelitianini menguji hubungan antara job resources dan work engagement, khususnya di sektor manufaktur otomotif berupa ban mobil di Indonesia yang telah berdiri sejak 1994, yaitu PT Elangperdana Tyre Industry. Selama 34 tahun perusahaan telah melewati berbagai kondisi dan situasi ekonomi di Indonesia. Laporan tren ketenagakerjaan dan sosial tahun 2017 dari ILO, bahwa pekerjaan di sektor manufaktur telah berkembang pesat pada tahun 1990-2016. Pada tahun 2017, sektor manufaktur hanya mengalami perkembangan $4,4 \%$ saja dibandingkan dengan sektor jasa yang mencapai $7 \%$, akan tetapi penyerapan tenaga kerja terbesar tetap pada sektor manufaktur. Pasar global tidak bisa dipisahkan dari PT Elang Perdana Tyre Industry (EPTI) yang memasarkan $85 \%$ produknya ke mancanegara. Peningkatan mutu produk menjadi strategi utama perusahaan untuk dapat bertahan dalam persaingan usaha.

Pengelolaan sumber daya manusia menjadi fokus yang penting, menyangkut kondisi kerja, pengetahuan, sikap dan perilaku karyawan, yang telah dirangkum dalam sasaran mutu perusahaan. Penelitian mengenai dampak work engagement di bidang industri manufaktur menunjukkan hubungan dengan keselamatan kerja, moral pekerja dan kesejahteraan di tempat kerja.Work engagement berhubungan negatif dengan intense keluar (turnover) karyawan (Ayu, 2015). Pekerja yang memiliki work engagement akan menunjukkan keterikatan emosional pada pekerjaan yang akan menurunkan ketidakhadiran kerja, menurunkan kecelakaan kerja, dan menunjukkan peningkatan produktifitas sehingga dampaknya akan meningkatkan keuntungan perusahaan (Wagner dan Harter, 2006).

Engagement karyawan sangat penting dalam membantu perusahaan meningkatkan daya saing dalam peningkatan mutu produk. Akan tetapi, karyawan membutuhkan kondisi mental yang possitif dan dapat memotivasi dalam bekerja. Hobfoll (2001) menjelaskan bahwa semua jenis job resources dapat menjadi potensi motivasi karyawan dan menjadi sangat berguna ketika dibutuhkan.Hasil penelitian yang telah dikemukakan menyatakan bahwa work engagement penting untuk ditingkatkan di organisasi. Karyawan yang tidak engaged dapat menimbulkan permasalahan seperti, kondisi pekerjaan yang kehilangan komitmen dan motivasi kerja (Aktouf, 1992), meningkatnya kecenderungan untuk meninggalkan organisasi atau perusahannya (turnover),rendahnya tingkat kehadiran dan menurunnya kinerja karyawan (Caldwel et al. 1992).

Telah dijelaskan bahwaJCdan LMX merupakan job resources sebagai antesenden dari work engagement. Berdasarkan isu yang dibangun tujuan dari penelitian ini Pertama,menganalisis pengaruh job characteristicsterhadap work engagement. Kedua, menganalisis pengaruh leader-member exchange terhadap work engagement. Ketiga, menguji peran moderasi LMX pada pengaruh job characteristics terhadap work engagement. 


\section{METODE PENELITIAN}

Penelitian dilakukan di PT Elangperdana Tyre Industry yang bertempat di Citeureup kabupaten Bogor, bergerak dalam industri ban mobil, berdiri sejak tahun 1997. Pengambilan data dilakukan pada bulan Mei-Juli 2018. Karyawan yang menjadi responden mengisi langsung kuesioner (self administered). Teknik pengambilan sampel disproportional stratified random, yaitu, cara pengambilan sampel populasi yang mempunyai anggota atau unsur yang tidak homogen dan berstrata secara tidak proporsional dari setiap elemen populasi yang dijadikan sampel dan pengambilan sampel dilakukan secara random. Sebanyak 395 responden berpartisipasi pada penelitian ini yang jumlahnya minimalnya didapatkan menurut rumus slovin dari jumlah populasi yang menjadi kriteria dalam penelitian ini, yaitu dari 1820 karyawan tetap di perusahaan. Karyawan tetap diasumsikan telah memahami pekerjaannya, telah menguasai berbagai proses dan variasi pekerjaan. Untuk pengujian validitas dan reliabilitas konstrak digunakan confirmatory factor analisys (CFA) (Wijayanto, 2008). Sedangkan, pengujian hipotesis penelitian dilakukan dengan Structural Equation Modeling (SEM). Pengolahan data baik CFA mau pun SEM menggunakan software Lisrel 8.3.

Variabel pertama yakni job characteristics diukur dengan menggunakan 20 item yang mewakili 5 dimensi konsep karakteristik inti pekerjaan.Pernyataan kuesioner disusun oleh Hackman danOldham(1975) dan dikembangkan oleh Morgenson dan Humprey (2006). Variabel kedua, LMX dikembangkan oleh Liden dan Maslyn (1998) sebanyak 12 item yang masing-masing mewakili 4 dimensi. Variabel pertama dan kedua diukur dengan skala semantic deffential dengan interval 1-7, dengan dua kutub yang bertentangan dari sangat tidak setuju sampai sangat setuju. Variabel ketiga, yaitu work engagement, dengan 3 dimensi, yaitu vigor, dedication dan absorption. Diukur juga dengan skala semantic deffential dengan interval 1-7, dengan dua kutub yang bertentangan dari tidak pernah sampai sangat sering.

Berdasarkan Gambar 1, penelitian akan menguji 3 (tiga) hipotesis. Hipotesis pertama (H1) adalah pengaruh positif job characteristicsterhadap work engagement. Hipotesis pertama dibangun teori Job DemandResources (JD-R) (Bakker dan Demerouti, 2007). Job Resources (sumber daya dari pekerjaan) dapat menurunkan job demand (tuntutan pekerjaan) yang berhubungan dengan biaya fisiologis dan psikologis, membantu mencapai target dan tujuan pekerjaan serta dapat menstimulasi pertumbuhan, pembelajaran dan pengembangan pribadi karyawan. Job resources dapat berperan sebagai motivasi intriksik. Faktor pekerjaan dalam teori motivasi kerja merupakan motivasi intrinsik yang dapat mendorong karyawan untuk melakukan pekerjaan sebaik mungkin.

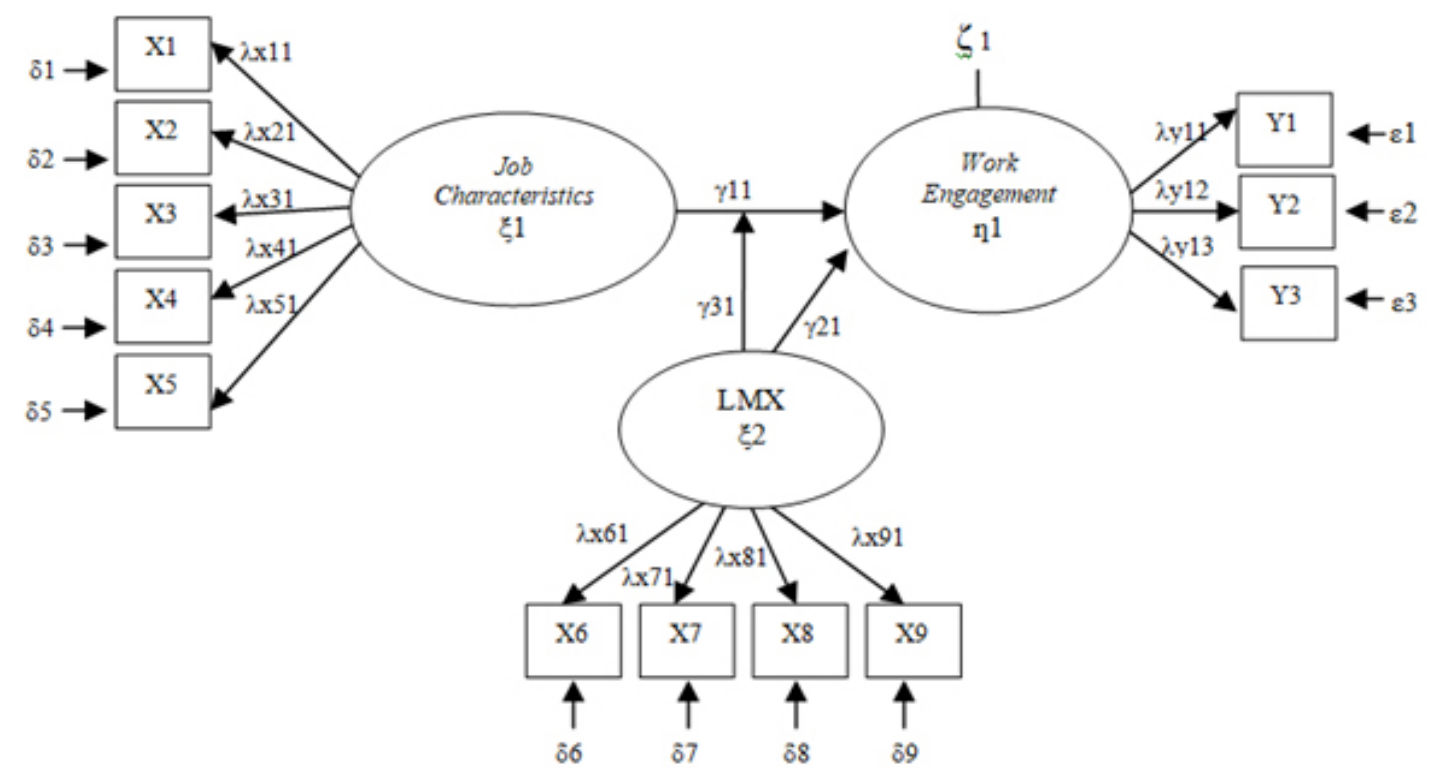

Gambar 1. Model SEM pengaruh job characteristics dan leader member exchange (LMX) terhadap work engagement 
Khan (1990) mengemukakan bahwa pekerjaan yang dilakukan oleh karyawan dapat mendorong engagement karyawan, karena karyawan memiliki peran dalam kinerjanya (role performance). Job characteristics mendorong karyawan merasakan kondisi psikologis kebermaknaan (meaningfulness) yang menjadikan karyawan engaged pada pekerjaan. Menurut Saks (2006) job characteristics berpengaruh langsung terhadap tingkat work engagement. Melalui teori ini menjelaskan bahwa job characteristics memiliki peran penting terkait dengan sikap kerja karyawan di dalam organisasi. Tingginya tingkat dimensi-dimensi pekerjaan menyebabkan tingkat kepuasan, motivasi, dan kinerja yang tinggi, serta rendahnya tingkat absensi, dan turnover karyawan.

H1 : Job characteritics berpengaruh terhadap work engagement.

Hipotesis kedua (H2) pengaruh positif LMX terhadap work engagement. Hipotesis ini dibangun berdasarkan adanya pertukaran antara karyawan dan pemimpin/ atasan.Hubungan karyawan dengan atasan yang juga dikenal dengan LMX menjelaskan berinteraksi satu sama lain. Karyawan yang mengalami hubungan LMX berkualitas tinggi cenderung berkontribusi melampaui persyaratan minimum pekerjaan karena perasaan bersama, kesetiaan, komitmen, dukungan, dan kepercayaan, yang kesemuanya meningkat dari waktu ke waktu (Maslyn dan Uhl-Bien, 2001). Pemberdayaan pegawai dan kualitas hubungan atasan dengan anggotanya, memiliki dampak sinergis pada hasil kerja. Organisasi akan memperoleh banyak manfaat dengan memiliki atasan yang mampu menciptakan hubungan kerja yang baik (Northouse, 2013). Menurut Katrinli et al. (2010) kualitas hubungan atasan dan bawahan berdasarkan kepercayaan dan komitmen yang saling menguntungkan. Pada LMX yang tinggi karyawan menerima dukungan dari atasannya secara formal maupun informal dan adanya keterbukaan dalam komunikasi sehingga akan meningkatkan engagement karyawan dalam bekerja.

\section{H2 : LMX berpengaruh terhadap work engagement.}

Hipotesis ketiga $(\mathrm{H} 3)$ adalah peran moderasi LMX terhadap pengaruh job characteristics terhadap work engagement. Karyawan yang memiliki orientasi untuk dapat berkontribusi kepada atasannya sangat dibutuhkan untuk keberlangsungan LMX yang tinggi, sehingga berdampak pada kinerja (Liden dan Maslyn,
1998). Ketika atasan dan karyawan memiliki hubungan yang baik maka karyawan dan organisasi akan lebih berprestasi. Karyawan yang mengalami hubungan LMX berkualitas rendah tidak mungkin berkontribusi melampaui upaya minimal yang dibutuhkan untuk tetap bekerja (Cropanzano dan Mitchell, 2005). LMX yang buruk akan menjadi tuntutan pekerjaan (job demand) akan mempengaruhi hubungan antara job resources, yaitu job characteristics dengan work engagement.

Penelitian dari Sullivan (2017) menegaskan bahwa job characteristics akan meningkatkan komitmen pada organisasi. Konsep komitmen organisasi menurut Bakker (2011) merupakan bagian dari konsep work engagement. Karyawan tidak akan terpengaruh jika organisasi menciptakan rancangan kerja yang disukai dan membuat karyawan mendapat penghargaan pada pekerjaan yang dikerjakannya. Rancangan pekerjaan yang baik dapat memotivasi karyawan untuk terus berkerja, walaupun hubungan dengan atasan tidak mendukung karyawan. Karyawan yang memiliki work engagement merupakan karyawan yang berorientasi pada organisasi. Karyawan dapat membantu organisasi atau pun perusahaan mencapai tujuannya.

H3 : LMX memoderasi pengaruh job characteristics dan work engagement.

\section{HASIL}

\section{Karakteristik Responden}

Responden yang berjumlah 395 orang dengan rincian $96,2 \%$ berjenis kelamin laki-laki dan sisanya $3,8 \%$ berjenis kelamin perempuan. Usia responden didominasi oleh kelompok dengan rentang usia 3140 tahun sebesar 54,94\%. Tingkat pendidikan dengan jenjang SMA sebanyak 83,8\% dan Diploma 5,57 \% dan S1 sebanyak 10,63\%. Masa kerja responden 2-3 tahun sebanyaj $8,86 \%$, 4-5 tahun $4.81 \%$ dan lebih dari limat tahun $86,33 \%$. Responden berdasarkan jabatan, yaitu, staf sebanyak $8,61 \%$, operator $44,81 \%$, teknisi $12,91 \%$, leader $12,66 \%$, foreman $16,71 \%$, supervisor $3,54 \%$ dan manager $0,76 \%$.

\section{Uji Deskriptif}

Hasil uji deskriptif pada Tabel 1 menunjukkan mean dan standar deviasi setiap variabel. Dengan standar deviasi yang paling lebar pada variabel LMX artinya 
variasi jawabannya cukup bervariasi berkiasar pada mean 4,26-6,30. Pada variabel job characteristics memiliki variasi jawbaan 5,13-6,59 dan work engagement memiliki variasi jawaban 4,62-6,38, yang lebih mendekati mean.

Tabel 1 Hasil uji deskriptif

\begin{tabular}{lcc}
\hline Variabel & Mean & Standar Deviasi \\
\hline Job Characteristics & 5,86 & 0,73 \\
LMX & 5,28 & 1,02 \\
Work Engagement & 5,5 & 0,88 \\
\hline
\end{tabular}

\section{Uji Validitas dan Reliabilitas}

Validitas merupakan tingkat keakuratan yang dicapai oleh sebuah indikator dalam menilai sesuatu kontruk, sedangkan reliabilitas merupakan ukuran untuk konsistensi internal dari indikator sebuah konstruk yang menunjukkan tingkat dimana maing-masing indikator mengindikasikan sebuah konstruk yang umum (Ferdinand, 2002). Validitas dapat diketahui dari nilai Standardized Loading Factor (SLF) pada uji Confirmatory Factor Analysis (CFA) yang menggambarkan kemampuan variabel teramati dalam mengukur variabel laten. Nilai SLF yang baik ialah $\geq$ 0,05 . Nilai SLF setiap indikator terhadap dimensinya mau pun setiap dimensi terhadap kontruknya sudah memenuhi parameter, yaitu $\geq 0.05$ untuk setiap konstruk, baik job characteristics, LMX mau pun work engagement. Begitu pun dengan parameter reliabilitas konstruk, yaitu Construct Reliability (CR) dengan nilai $\geq 0,70$ dan Variance Extracted (VE) dengan nilai $\geq 0,50$, telah dipenuhi dalam penelitian ini, sehingga dapat dilanjutkan pada tahap analisis kecocokan model pengukuran.

\section{Analisis Kecocokan Model Pengukuran}

Menurut Hair et al. (2014) evaluasi terhadap tingkat kecocokan data dengan model dilakukan melalui beberapa tahapan, yaitu kecocokan model pengukuran (measurement model fit) dan kecocokan model struktural (structural model fit). Pengujian goodness of fit menunjukan dengan menggunakan pengujian chisquare diperoleh kesimpulan nilai-p $0,00<0,05$ artinya model yang dihasilkan kurang good fit. Salah satu kelemahan dari model SEM adalah sensitif dengan jumlah sampel dimana jumlah sampel yang besar cenderung menghasilkan nilai chisquare yang tinggi yang mengakibatkan model tidak goodness of fit. Oleh karena itu, SEM memberikan alternatif penggunaan indikator goodness of fit yang lain, yaitu GFI, IFI, NFI dan CFI menghasilkan nilai $>0,90$ yang artinya model yang dihasilkan sudah goodness of fit, karena hasil kesimpulan model goodness of fit maka pengujian hipotesis teori dapat dilakukan. Hasil pengolahan disajikan pada Tabel 2.

Tabel 2 Nilai pengujian model

\begin{tabular}{lccc}
\hline \multicolumn{1}{c}{ Goodness-of-Fit } & Cutt-off-Value & Hasil & Kesimpulan \\
\hline RMSEA & $<0,80$ & 0,074 & Good fit \\
GFI & $>0,90$ & 0,99 & Good fit \\
AGFI & $>0,90$ & 0,98 & Good fit \\
IFI & $>0,90$ & 0,99 & Good fit \\
NFI & $>0,90$ & 0,99 & Good fit \\
CFI & $>0,90$ & 0,99 & Good fit \\
\hline
\end{tabular}

\section{Kecocokan model struktural (structural model fit)}

Tingkat signifikansi hubungan antar variabel, baik dimensi dengan variabel laten maupun antar variabel laten digunakan uji-t dengan tingkat signifikansi $\alpha=0.05$ $(\mathrm{t} \alpha / 2=1.96)$. Sementara itu nilai estimasi faktor muatan model (standardize loading factor) digunakan untuk mengukur besar pengaruh antara variabel laten atau bobot antara indikator ke variabel laten dengan nilai 1 sebagai nilai maksimum.

Hasil pengujian hipotesis ditunjukan oleh Gambar 2. Hasil analisis, menunjukan bahwa job characteristics dan LMX berpengaruh terhadap work engagement. Jobcharacteristics berpengaruh positif terhadap work engagement sebesar 0,24, semakin tinggi job characteristics maka akan semakin meningkatkan work engagement karyawan. LMX berpengaruh positif pada work engagement sebesar 0,22 artinya semakin tinggi LMX maka akan semakin meningkatkan work engagement. Interaksi antara job characteristics dan LMX, berpengaruh positif sebesar 0,41 terhadap work engagement. Moderasi variabel LMX terhadap job characteristics semakin memperkuat pengaruh terhadap work engagement. Keseluruhan model memiliki $\mathrm{R}$ 20,49 artinya model menggambarkan $49 \%$ atas kondisi yang sesungguhnya dan $51 \%$ lainnya merupakan faktorfaktor lain yang dapat mempengaruhi work engagement karyawan di PT Elangperdana Tyre Industry.

\section{Pengujian pengaruh variabel job characteristics terhadap work engagement}

Hasil uji-t yang dapat dilihat pada Tabel 3 bahwa nilai uji-t job characteristics sebesar 9,04. Hasil ini 
menyatakan $\mathrm{H} 0$ ditolak ( $\mathrm{t}$ hitung $>\mathrm{t}$ tabel) maka $\mathrm{H} 1$ diterima. Hasil uji hipotesis menunjukkan bahwa job characteristics berpengaruh terhadap work engagement dengan faktor muatan 0.24 , artinya semakin baik job characteristic akan semakin meningkatkan work engagement. Hasil pengujian hipotesis menunjukkan job characteristics berpengaruh langsung positif signifikan pada work engagement di perusahaan.
Hasil penelitian ini sesuai dengan hasil penelitian yang telah dilakukan oleh Sonnentag (2017) bahwa job characteristic adalah prototipikal pekerjaan yang dapat merangsang work engagemet karyawan. Menurut penelitian Khan (1990) job characteristics selama dapat menumbuhkan kebermaknaan (meaningfulness), ketersediaan (availability) dan keamanan (safety) dalam melakukan pekerjaan akan dapat memunculkan work engagement.

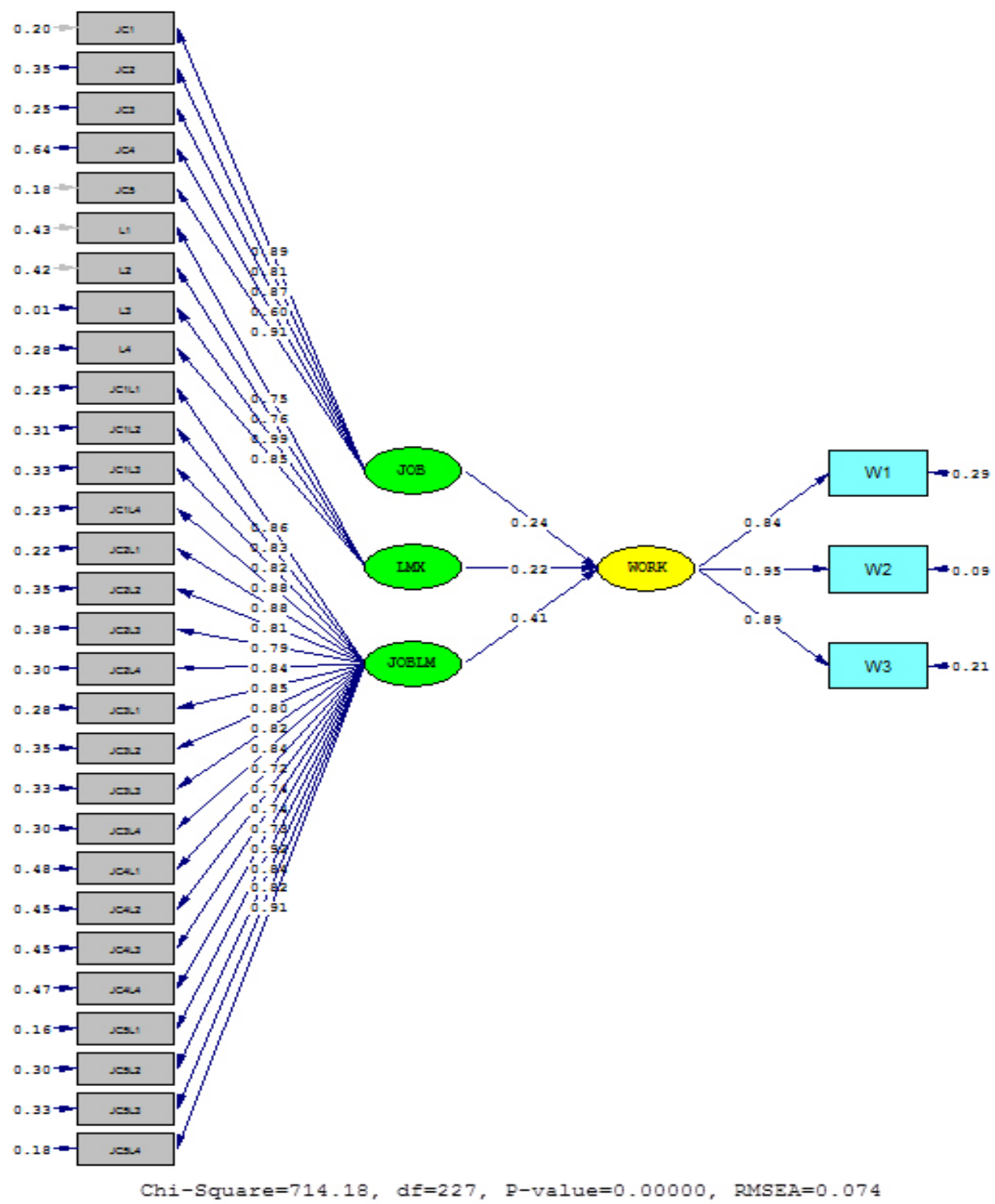

Gambar 2. Nilai SLF model pengukuran job characteristics dan LMX terhadap work engagement

Tabel 3. Nilai faktor muatan dan uji-t variabel laten eksogen dan endogen

\begin{tabular}{lccc}
\hline Variabel & Standardized loading faktor & t-hitung & Kesimpulan \\
\hline JOB $\rightarrow$ Work & 0,24 & $9,04^{*}$ & Signifikan \\
LMX $\rightarrow$ Work & 0,22 & $8,68^{*}$ & Signifikan \\
JOBLM $\rightarrow$ Work & 0,41 & $26,65^{*}$ & Signifikan \\
\hline
\end{tabular}


Menurut Robinson et al. (2006) job characteristics akan mendorong karyawan merasa dihargai dan dilibatkan (feeling valued and involved) karyawan dapat menyalurkan ide sehingga mereka dapat merasa berharga dan mendapat kesempatan untuk mengembangkan diri dalam pekerjaan. Sesuai dengan penjelasan Bakker (2011) bahwa interaksi karyawan dengan pekerjaan dapat memberikan pengalaman kebermaknaan secara psikologis dan merasa bertumbuh secara pribadi yang meningkatkan resources dan motivasi intrinsik karyawan.

\section{Pengujian pengaruh LMX terhadap Work Engagement}

Hasil uji-t yang dapat dilihat pada Tabel 3 bahwa nilai uji-t LMX sebesar 8.68, hasil ini menyatakan bahwa $\mathrm{H} 0$ ditolak (t-hitung $>$ t-tabel) sehingga H1 diterima. Hasil pengujian menunjukkan bahwa LMX berpengaruh langsung positif terhadap work engagement dengan nilai estimasi faktor muatan model sebesar 0.22 yang dapat dilihat pada Gambar 2. Hasil pengujian hipotesis ini merangkan bahwa apabila LMX dalam organisasi meningkat maka akan meningkatkan pula work engagement karyawan.

Hasil penelitian ini sesuai dengan penelitian Kendrick (2013) bahwa terdapat hubungan yang kuat antara work engagement dan LMX. Liden dan Maslyn (1998) menjelaskan bahwa LMX berpengaruh pada perilaku kerja karyawan. Kualitas LMX yang baik akan menjadikan karyawan in group dengan atasan, sebaliknya kualitas hubungan atasan dan bawahan yang buruk maka karyawan atau bawahan akan menjadi out goup. Kelompok in group adalah kelompok yang loyal dan mau melakukan tugas diluar deskripsi pekerjaanya. Sebaliknya dengan kelompok out group akan menunjukkan penurunan motivasi kerja dan cenderung mudah melakukan pekerjaan diluar harapan atasannya.

Menurut Katrinli et al. (2010) kualitas hubungan atasan dan bawahan berdasarkan kepercayaan dan komitmen yang saling menguntungkan. Pada LMX yang tinggi karyawan menerima dukungan dari atasannya secara formal mau pun informal dan adanya keterbukaan dalam komunikasi sehingga akan meningkatkan engagement karyawan dalam bekerja.

\section{Pengujian pengaruh LMX Sebagai Variabel Moderator pada Pengaruh Job Characteristic terhadap Work Engagement}

Berdasarkan hasil uji yang dapat dilihat pada Tabel 3 bahwa nilai uji-t LMX sebagai variabel moderator pada pengaruh antara job characteristics dan work engagement sebesar 26.65 ( $\mathrm{t}$ hitung $>\mathrm{t}$ tabel) 1,96 sehingga H3 diterima. LMX memperkuat pengaruh job characteristics terhadap work engagement dengan faktor muatan 0.41 yang juga dapat dilihat pada Gambar 2. Pengaruh job characteristic menjadi lebih kuat dengan adanya efek moderasi dari LMX. Hasil pengujian hipotesis ini memiliki arti bahwa jika karyawan PT ElangperdanaTyre Industry merasakan peningkatan job characteristics dan peningkatan LMX maka work engagement akan semakin meningkat pula.

Liden dan Graen (1980) menurut penelitiannya bahwa intensi hubungan atasan dan bawahan juga tergantung dari tuntutan karakteristik pekerjaan. Tidak semua pekerjaan menuntut adanya intervensi dan interaksi atasan dan bawahan yang sama. Untuk itu kualitas hubungan karyawan dengan atasannya dapat berbedabeda. Meskipun berbeda-beda hubungan setiap atasan dan karyawan sebaikya, menurut Baumruk (2004) bahwa pemimpin organisasi yang peduli dan menganggap bahwa karyawan berharga akan mengindikasikan peningkatkan work engagement.

Penelitian Aggarwal et al. (2011) hasilnya sejalan dengan hasil penelitian ini bahwa kualitas hubungan atasan dan bawahan terbentuk berdasarkan kepercayaan dan komitmen yang saling menguntungkan. Pada LMX yang tinggi karyawan menerima dukungan dari atasannya secara formal mau pun informal dan adanya keterbukaan dalam komunikasi sehingga akan meningkatkan engagement karyawan dalam bekerja. Hubungan yang baik ini yang dapat memoderasi pengaruh job characteristics terhadap work engagement menjadi lebih tinggi lagi.

\section{Implikasi Manajerial}

Implikasi yang dapat disarankan pada perusahaan untuk dimensi job characteristics yang memiliki loading factor paling tinggi adalah feedback (umpan balik) dan skill variety (keberagaman keterampilan) adalah establishing client relationship. Metode ini dapat dilakukan dengan memberikan kesempatan kepada karyawan untuk berhubungan langsung dengan 
klien atau pihak yang menerima hasil kerjanya. Cara ini membuat karyawan mengetahui seberapa baik hasil kerjanya untuk klien (feeback from job itself) dan mempelajari berbagai keahlian tambahan untuk berinteraksi dengan klien (skill variety).

Dimensi LMX yang memiliki loading factor tertinggi adalah contribution. Karyawan mengharapkan kontribusi dari atasan terhadap pekerjaannya. Atasan diharapkan meningkatkan involvement (keterlibatan) dalam pekerjaan karyawan, sehingga mengetahui kendala pekerjaan yang dihadapi oleh karyawan dan kemudian dapat memberikan solusi. Interaksi dimensi feedback dan affection memiliki nilai loading factor yang paling besar. Feedback agar diberikan secara positif dan menyenangkan terhadap bawahan sehingga dapat juga memunculkan rasa hormat terhadap profesionalitas atasan (professional respect).

\section{KESIMPULAN DAN SARAN}

\section{Kesimpulan}

Hasil penelitian pengaruh job characteristics dan LMX terhadap work engagement pada karyawan PT Elang Perdana Tyre Industri dapat disimpulkan tingkat job characteristics berada pada tingkat rataan yang tinggi menunjukkan bahwa responden memiliki karakteristik rancangan kerja yang baik dan memotivasi secara intrinsik. Karyawan termotivasi karena pekerjaan dapat mendorong pertumbuhan pribadi karyawan. LMX yang tinggi menunjukkan bahwa interaksi sosial antar karyawan sudah cukup baik. Dimensi yang paling berpengaruh dari LMX adalah contribution. Tingkat work engagement karyawan berada pada tingkat tinggi. Tingkat ini menunjukkan bahwa karyawan mempunyai semangat dan energi yang tinggi saat bekerja. Hasil penelitian menunjukkan bahwa job characteristics dan LMX memberikan pengaruh langsung positif terhadap work engagement karyawan, semakin baik tingkat job characteristics dan LMX maka akan terbentuk work engagement yang tinggi pada karyawan.

\section{Saran}

Saran yang dapat diberikan berdasarkan hasil penelitian untuk meningkatkan motivasi intriksik, yaitu, job characteristics dapat menjadi perhatian perusahaan agar karyawan merasa termotivasi dan engaged dengan pekerjaanya. LMX juga harus selalu dibangun oleh atasan diperusahaan untuk meningkatkan work engagement sebagai dukungan sosial yang merupakan motivasi ekstrinsik. Penelitian selanjutnya, dapat memperluas objek penelitian pada industri sejenis untuk dapat melihat gambaran work engagement pada industri yang sama dan dapat menambahkan dan menggunakan variabel lain yang dapat memengaruhi work engagement.

\section{DAFTAR PUSTAKA}

Aggarwal UA, Datta S, Blake-Beard S, Bhagarva S. 2011. Linking LMX, innovative work behaviour and turnover intentions: The mediating role of work engagement. Career Development International 17(3): 208-230. https://doi. org/10.1108/13620431211241063.

Aktouf O. 1992. Management and theories of organizations in the 1990s: toward a critical radical humanism. Academy of Management Review 17(3): 407-431. https://doi.org/10.5465/ amr.1992.4281975.

Ayu D. 2015. Pengaruh job demands, job resources dan personal resources terhadap work engagement. Jurnal Aplikasi Bisnis dan Manajemen (JABM) 1(1): 12-22. https://doi.org/10.17358/ JABM.1.1.12.

BakkerAB,SchaufelliWB.2008. Positiveorganizational behavior: engaged employees in flourishing organizations. Journal ofOrganizational Behavior 29:147-154. https://doi.org/10.1002/ job.515.

Bakker AB. 2011. An evidence-based model of work engagement. Current Direction in Psychological Science 20(4): 265-269. https:// doi.org/10.1177/0963721411414534.

Bakker AB, Demerouti E. 2007. The job demandsresources model: state of the art. Journal of Managerial Psychology 22:309-328.https://doi. org/10.1108/02683940710733115.

Bakker AB. 2014. Daily fluctuations in work engagment: An overview and current directions. European Psychologist 19(4): 227-236.https:// doi.org/10.1027/1016-9040/a000160.

Bakker AB, Bal PM. 2010. Weekly work engagement and performance: A study among starting teachers. Journal of Occupational and Organizational Psychology 83:189-206. https:// doi.org/10.1348/096317909X402596. 
Bakker AB, Leiter MP. 2010. Work engagement: A Handbook of Assential Theory and Research. New York: Psychology Press. https://doi. org/10.4324/9780203853047.

Bakker AB. 2011. An Evidence-Based Model of Work Engagement. Current Direction in Psychological Science 20(4): 265-269.https:// doi.org/10.1177/0963721411414534.

Bakker AB, Demerouti E, Brummelhuis LL. 2012. Work engagement, performance, and active learning: The role of conscientiousness. Journal of Vocational Behavior 80:555-564. https://doi. org/10.1016/j.jvb.2011.08.008.

Baumruk R. 2004. The missing line: The role of employee engagement in business success. Workspan 47:48-52.

Caldwell D, Chatman J, O'Reilly C. 1990. Building organizational commitment: a multiform study. Journal Occupational Psychology 63: 245261. https://doi.org/10.1111/j.2044-8325.1990. tb00525.x.

Cropanzano R, Mitchell MS. 2005. Social exchange theory: An interdisciplinary review. Journal of Management 31(6):874-900. https://doi. org/10.1177/0149206305279602.

Demerouti E, Bakker AB, Nachreiner F, Schaufeli WB. 2001. The job demands-resources model of burnout. Journal of Applied Psychology 86(3): 499-512. https://doi.org/10.1037/00219010.86.3.499.

Ferdinand. 2002. Metode Penelitian Manajemen: Pedoman penelitian untuk Skripsi, Tesis, dan Desertasi Ilmu Manajemen. Semarang: Badan Penerbit Universitas Diponegoro.

Graen G, Uhl-bienM. 1995. Relationship-based approach to leadership: development of leader member exchange (LMX) theory of leadership over 25 Years: applying a multi-level multidomain perspective. Leadership Quarterly 6(2): 219-24. https://doi.org/10.1016/10489843(95)90036-5.

Hackman JR, Oldham GR. 1975. Development of the job diagnostic survey. Journal of Applied Psychology 60(2): 159-170. https://doi. org $/ 10.1037 / \mathrm{h} 0076546$.

Hair JF, Black WC, Babin BJ, Anderson RE.2014. Multivariate Data Analysis. Seventh Edition. Prentice Hall, Upper Saddle River, New Jersey.

Hakanen JJ, Koivumäki J. 2014. Engaged or exhausted: How does it affect dentists clinical productivity. Burnout Research 1:12-18.https:// doi.org/10.1016/j.burn.2014.02.002.

Hanaysha J. 2016. Improving employee productivity through work engagement: Empirical evidence from higher education sector. Industrial Journal of Industrial engineering Computations 6:61-70. https://doi.org/10.5267/j.msl.2015.11.006.

Hobfoll SE. 2001. The influence of culture, community, and the nested-self in the stress process: Advancing conservation of resources theory. Applied Psychology 50: 337-370.https://doi. org/10.1111/1464-0597.00062.

KahnWA. 1990. Pychological conditions of personal engagement and disengagement at work. Academy of Management Journal 33: 692-724. https://doi.org/10.5465/256287.

Kahn WA. 1992. To be fully there: psychological presence at work. Human Relations 45: 321-349. https://doi.org/10.1177/001872679204500402.

Katrinli A, Atabay G, Gunay G, Cangarli BG. 2010. Perception of organizational politics and LMX: Linkages in distributive justice and job statisfaction. African Journal of Business Management 4(14): 3110-3121.

Kendrick KC. 2013. The relationships between employee engagement, work engagement, and leader-member exchange [disertasi]. Chicago: The Chicago School of Professional Psychology

Liden RC, Maslyn JM. 1998. Multidimensionality of leader-member exchange: An empirical asessment through scale development. Journal of Management 24(1): 43-72. https://doi. org/10.1016/S0149-2063(99)80053-1.

Macey WH, Schneider B. 2008. The meaning of employee engagement. Industrial and Organizational Psychology 1(1): 3-30. https:// doi.org/10.1111/j.1754-9434.2007.0002.x.

Meyer JP, Gagne M. 2008. Employee engagement from aself-determination theory perspective.Industrial and Organizational Psychology 1: 60-62. https:// doi.org/10.1111/j.1754-9434.2007.00010.x.

Maslyn J, Uhl-Bien M. 2001. Leader member exchange and its dimension: Eff.ect of self-effort and other's effort on relatipnship quality. Journal of Applied Psychology 86(4):697-708. https://doi. org/10.1037/0021-9010.86.4.697.

Morgenson PF, Humphrey SE. 2006. The workdesign questionnaire (WDQ): Developing and validating a comprehensive measure for asseing job design and the nature of work. Journal of Applied Psychology 91(6): 1321-1339. https:// doi.org/10.1037/0021-9010.91.6.1321 
Noe RA, Hollenbeck JR, Gerhart B, Wright PM. 2006. Manajemen Sumber Daya Manusia: Mencapai Keunggulan Bersaing. Ed ke-6. Buku I. Jakarta: Salemba Empat.

Northouse P. 2013. Leadership: Theory and practice. (6ed.). Thousand Oaks, CA: Sage Publishing.

Saks A. 2006. Antecedents and consequences of employee engagement. Journal of Managerial Psychology 21(7):600-619. https://doi. org/10.1108/02683940610690169.

Schaufeli WB, Bakker A. 2004. Job demands, job resources, and their relationship with burnout and engagement: a multi-sample study. Journal of Organizational Behavior 25:293-315. https:// doi.org/10.1002/job.248.

Schaufeli WB, Salanova M, González-romá V, Bakker AB. 2002. The measurement of engagement and burnout: A two sample confirmatory factor analytic approach. Journal of Happiness Studies 3(1): 71-92. https://doi.org/10.1023/ A:1015630930326.
Sullivan C. 2017. The Moderating Effect of LeaderMember Exchange on the Relationship between Job Characteristics and Organizational Commitment[tesis].

Sonnentag S. 2017. A task-level perspective on work engagement: a new approach that helps to differentiate the concept of engagement and burnout. Burnout Research 5: 12-20. https://doi. org/10.1016/j.burn.2017.04.001.

Wagner R, Harter JK. 2006. 12: The Great Elements of Managing. Washington DC: The Gallup Organization.

Wellins R, Benthal P, Phelps, M. 2006. Employee Engagement: The Key to Realizing Competitive Advantage. Development Dimensions International, Inc.

Wijayanto SH. 2008. Structural Equation Modeling dengan Lisrel 8.8. Yogyakarta: Graha Ilmu 